\title{
Precipitation Patterns and Rainfall Erosivity Return Period Under Savanna Conditions in Formosa, Goiás, Brazil
}

\author{
Aline Franciel de Andrade \\ School of Agronomy, Federal University of Goiás, Goiânia, Brazil \\ Roriz Luciano Machado (Corresponding author) \\ Federal Institute Goiano - Campus Ceres, Highway GO-154, Km 03, s / n, 76300-000, \\ Ceres, GO, Brazil. E-mail: roriz.machado@ifgoiano.edu.br
}

Cássia Cristina Rezende

School of Agronomy, Federal University of Goiás, Goiânia, Brazil

Elizabete Alves Ferreira

National Meteorological Institute / 10th DISME. Goiânia, Brazil

Murilo Alceu de Águas

Federal Institute Goiano - Campus Ceres, Ceres, GO, Brazil

Vladia Correchel

School of Agronomy, Federal University of Goiás, Goiânia, Brazil

Daniel Fonseca de Carvalho

Federal Rural University of Rio de Janeiro, Seropédica, Brazil

Received: Sep. 16, 2020

doi:10.5296/jas.v8i4.17837
Accepted: Oct. 15, $2020 \quad$ Published: Oct. 15, 2020

URL: https://doi.org/10.5296/jas.v8i4.17837 


\section{Abstract}

Losses of soil and nutrients affect a large part of agricultural areas in tropical regions, regardless of the level of technology adopted. This study evaluated the physical attributes and erosivity indices associated with rainfall patterns and return periods in the region of Formosa, State of Goiás, Brazil. Using series of pluviographic (2002-2008) and pluviometric (1975-1998), the erosive potential ( $\mathrm{EI}_{30}$ and $\left.\mathrm{KE}>25\right)$, rainfall patterns (advanced, intermediate and delayed) and the erosivity associated with the rainfall return periods were determined. The average annual rainfall of the region was $1,391.6 \mathrm{~mm}$ with $87.4 \%$ of the rains concentrated in October to March. The average annual values of $\mathrm{EI}_{30}$ and $\mathrm{KE}>25$ corresponded to 8,041.6 $\mathrm{MJ} \mathrm{mm} \mathrm{ha}^{-1} \mathrm{~h}^{-1}$ year $^{-1}$ and 125.7 $\mathrm{MJ} \mathrm{ha}^{-1}$ year $^{-1}$, respectively. The months of the year did not differ based on rainfall pattern. The advanced hydrological pattern had the highest frequency of occurrence, followed by the delayed and intermediate patterns. The highest $\mathrm{EI}_{30}$ and $\mathrm{KE}>25$ indices for individual rainfall seasons occurred under the intermediate and the advanced patterns in February and under the intermediate pattern in October for the index KE>25. The average annual erosivity index ( $\mathrm{R}$ factor of USLE) $\left(8,041.6 \mathrm{MJ} \mathrm{mm} \mathrm{ha}{ }^{-1} \mathrm{~h}^{-1}\right.$ year $\left.^{-1}\right)$ is expected to occur at least once every 1.89 years, corresponding to a probability of occurrence of $52.84 \%$. The average annual values of $\mathrm{EI}_{30}$ estimated for the return periods of 2, 5, 10, 25, 50 and 100 years were 8,230, 10,225, 10,889, $11,222,11,421$ and $11,488 \mathrm{MJ} \mathrm{mm} \mathrm{ha}^{-1} \mathrm{~h}^{-1}$ year $^{-1}$, respectively.

Keywords: Soil conservation, USLE, R factor, hydrological patterns

\section{Introduction}

Water erosion is one of the main causes of soil degradation and environmental contamination. The extent of water erosion and can be estimated using the Universal Soil Loss Equation (USLE) (Wischmeier \& Smith, 1978). This equation is used to facilitate the design of erosion control structures, assess soil management practices and conduct environmental planning (Back et al., 2019).

The erosive process depends on the capacity of the rain to produce erosion, i.e., on its erosivity ( $\mathrm{R}$ factor) as well as other factors (Wischmeier \& Smith, 1958). Thus knowledge of the patterns and distribution of rainfall erosivity is extremely important in estimating the occurrence of periods of erosion in a region (Almagro et al., 2017). This information facilitates the reduction of costs associated with losses of soil, water and nutrients that are found in the superficial most fertile layers of soil that are first removed by erosive processes (Bertol et al., 2017).

Numerous studies in Brazil have sought to identify the erosivity index that is closely related with soil losses (Marques et al., 1997; Silva et al., 1997a; Silva et al., 1997b; Cassol et al., 2008; Machado et al., 2013).According to by Wischmeier \& Smith (1958) and Wischmeier (1959), the product of the rainfall's kinetic energy with its maximum intensity in 30 min (the $\mathrm{EI}_{30}$ index ) best estimates soil erosivity; this index is currently used to obtain the R factor of the Universal Soil Loss Equation (USLE). Although the $\mathrm{EI}_{30}$ index was developed for use in temperate regions, it has been used with success in different localities in Brazil (Marques et 
al., 1997; Silva et al., 1997a; Bertol et al., 2002). In tropical regions, it is recommended that an index of KE>25 (Hudson, 1995), which is calculated from the kinetic energy of rainfalls with intensity above $25 \mathrm{~mm} \mathrm{~h}^{-1}$, be used.

Rainfall characteristics are a crucial factor in determining the variability in soil losses as evidenced by erosion plot experiments (Ran et al., 2012). However, understanding the relationship between erosivity and soil losses poses a challenge due to the absence of knowledge on the physical characteristics of rainfall (Wischmeier, 1959; Arai et al., 2010).

On different occasions, rainfall of equal magnitude can lead to varying levels of soil losses based on the moment of occurrence of the rainfall's peak intensity relative to its' total duration (Flanagan et al., 1988; Eltz et al., 2001; Aquino et al., 2013). The current evaluation aims to define the rainfall patterns (Horner \& Jens, 1942) that are known to influence the erosive process, especially runoff, soil loss and particle distribution (Wang et al., 2016). Another factor known to influence rainfall erosivity is the return period associated with the rainfall, since the greater the recurrence of rain, the greater its erosive potential. When Edwards \& Owens (1991) studied soil losses in nine micro-basins in Ohio - USA, they concluded that five extreme patterns of rainfall were responsible for $66 \%$ of the soil losses and the return period associated with these patterns exceeded 100 years of recurrence.

The municipality of Formosa and all the eastern region of Goiás (GO) have experienced expansive socio-economic growth in the last few decades. The gross domestic product (GDP) of the agricultural sector increased by $135.6 \%$ between 2010 and 2017 (IBGE, 2017). Formosa is comprised of a region of about one million hectares under agricultural use with $20 \%$ of this area being irrigated. It presents a highly technified production region with the farming of beans, corn, soy, horticultural and wheat crops that has industries installed for the processing of cereals and is equipped with superb logistical structure (Tejon, 2018). In view of this, research is required to inform improvements in soil quality such as the estimation of factors related erosion degradation to support conservation planning (Schick et al., 2014; Valvassori \& Back, 2014). Thus, this study was conducted to evaluate the physical attributes and erosivity indices associated with rainfall patterns and return periods in the region of Formosa - GO, Brazil.

\section{Material and Methods}

The study was conducted in Formosa-GO, Brazil, which has Aw (tropical savanna climate), characterized by hot, rainy summers and mild, dry winters based on Köppen's classification (Alvares et al., 2013). The regional topography is predominantly flat, with an altitude of 927 $\mathrm{m}$, an average annual temperature of $22.1^{\circ} \mathrm{C}$ and savanna vegetation (Climate-Data.org., n.d. 2020). The municipality is located in the eastern region of Goiás (GO) state, at $15.55^{\circ}$ South latitude and $47.34^{\circ}$ West longitude.

The study used daily pluviographic data from 2002 to 2008 from Formosa station $\left(15^{\circ} 32^{\prime}\right.$ $56.04 \mathrm{~S}^{\prime \prime}$ and $47^{\circ} 20^{\prime} 17.16^{\prime \prime} \mathrm{W}$ ), code 01547003 , belonging to National Meteorological Institute of Brazil (INMET), with temporal resolution of 10 min and precision of $0.2 \mathrm{~mm}$, which were digitized in an electronic spreadsheet. After individualization of rainfalls, 
CHUVEROS software was used to calculate the erosivity indices $\mathrm{EI}_{30}$ (Wischmeier \& Smith, 1958) and KE> 25 (Hudson, 1995), and classify the rainfalls in terms of rainfall patterns into three categories: Advanced, Intermediate and Delayed. This software program also computes the number of rainfall events, rainfall depth and other physical attributes of rainfall.

As most pluviographic databases in Brazil, information pertaining to the minimum period for obtaining the $\mathrm{R}$ factor of the USLE (i.e. 22 years) is not available in station 01547003 (Wischmeier \& Smith, 1978). In place of this, pluviometric data which have been used due to their greater availability and quality, and due to their correlation with pluviographic from the same meteorological station or a nearby station, were used (Machado et al., 2013).

Using pluviometric series of the same meteorological station, available at the Hidroweb/ANA database, regression analyses were conducted to assess the relationship between the rainfall erosivity indices $\left(\mathrm{EI}_{30}\right.$ and $\left.\mathrm{KE}>25\right)$, which obtained by means of pluviograms and pluviometric data of average monthly precipitation (p), for equal periods of the series. This process provided the models: $\mathrm{EI}_{30}=5.3945 \mathrm{p}+44.553\left(\mathrm{R}^{2}=0.96\right)$ and $\mathrm{KE}>25=0.0865 \mathrm{p}+$ $0.446\left(\mathrm{R}^{2}=0.97\right)$. Despite the data being obtained from the same meteorological station, these equations were further evaluated using confidence interval (CI) analysis (Moreti et al., 2003), that demonstrated the comparability of the pluviometric series (1975 to 1998) to the pluviographic series (2002 to 2008).

The historical pluviometric series and the equations generated were then used to calculate the erosivity indices ( $\mathrm{EI}_{30}$ and $\mathrm{KE}>25$ ) for each month, within each year, as done by Moreti et al. (2003). The sum of the indices from each month was used to calculate the erosivity of that specific year for all the years between 1975 and 2008, (except for the years 1979, 1999, 2000 and 2001, due to historical series failures). These data were then used to evaluate the monthly, annual and average annual distribution, as well as to determine the probability of occurrence (P) and return period (T) of the erosivity indices.

To fit the data with Log-normal distribution typical of hydrological events, (Roque et al., 2001 ), the values of the erosivity indices ( $\mathrm{EI}_{30}$ and $\left.\mathrm{KE}>25\right)$ were put in decreasing order associated with a column of increasing values ( 1 to 30 ). Then, the value of the frequency coefficient $(Z)$ was estimated using equation 1 :

$$
\mathrm{Z}=\frac{\log (\mathrm{EI})-\mathrm{EII}}{\mathrm{SDI}}
$$

where:

$\mathrm{EI}=$ erosivity index;

$\overline{\mathrm{IE}} 1=$ mean of the logarithm of the EI values; and

$\mathrm{SDl}=$ standard deviation of the logarithm of the EI values.

Following this, the values of theoretical probability $(\mathrm{P})$ were estimated using the log-normal probability distribution in an MsExcel application. To verify the data fit to the log-normal 
distribution, the Kolmogorov-Smirnov (K-S) adherence test was used at 0.05 probability level (Evangelista et al., 2006). In this analysis, for each value of order, the difference between calculated probability and the theoretical value was estimated. Lastly, the theoretical values of probability, return period and erosivity indices were used to generate (in the Matlab 2000) environment curves and linear equations to allow the estimation of $\mathrm{EI}_{30}$ and $\mathrm{KE}>25$ for different return periods $(2,5,10,20,50$ and 100 years) and probability of occurrence of erosivity indices, according to Roque et al. (2001) and Evangelista et al. (2006).

Cluster analysis was performed using the Ward`s method and Euclidean distance with the variables $\mathrm{EI}_{30}$ and $\mathrm{KE}>25$ for the 12 months (treatments) of the year in the series from 1974 to 2014 using the software Statistica 12.0. To evaluate the effect of months of the year and rainfall patterns on the attributes rainfall depth and the erosivity indices (obtained from pluviographs) the data were subjected to analysis of variance (ANOVA) and means comparison by Scott-Knott test (0.05 level), using the software SISVAR (Ferreira et al., 2007). The data were analyzed in completely randomized design in factorial scheme (7 x 3), corresponding to the treatments: months of the rainy period (October to April, 7 months) and rainfall patterns (3).

\section{Results and Discussion}

The average annual rainfall observed in the station of Formosa (GO) between 1975 and 2008 was $1,428.2 \mathrm{~mm}$. From October to April (considered the rainy period), $94.5 \%$ of the average annual rainfall fell, and this period was favorable to summer planting (predominant crops in the municipality Formosa: soy, corn and bean), as well as second-crop planting (predominant crops in the region corn, sorghum, millet, wheat, oats and buckwheat) in the region (Figure 1). With $92.3 \%$ of the annual erosivity ( $\mathrm{EI}_{30}$ ) being concentrated to this period. The erosivity indices $\mathrm{EI}_{30}$ and $\mathrm{KE}>25$ were proportional the monthly rainfall accumulated along the year. May to September period (mainly from June to August) with lower levels of rainfall, and consequently the erosive potential (Figure 1), characterizes the dry season in central Brazil.

With the cluster analysis (Figure 2), it was possible to separate two major groups of months that differed (dissimilarity close to 100\%) with respect to rainfall erosivity (EI30 and KE>25), but had similar characteristics within each group. The period from April to October (comprising May and September) differed from that from November to March (which is part of October to April), in which the highest annual erosivity is concentrated, in agreement with previous results (Figure 1). 


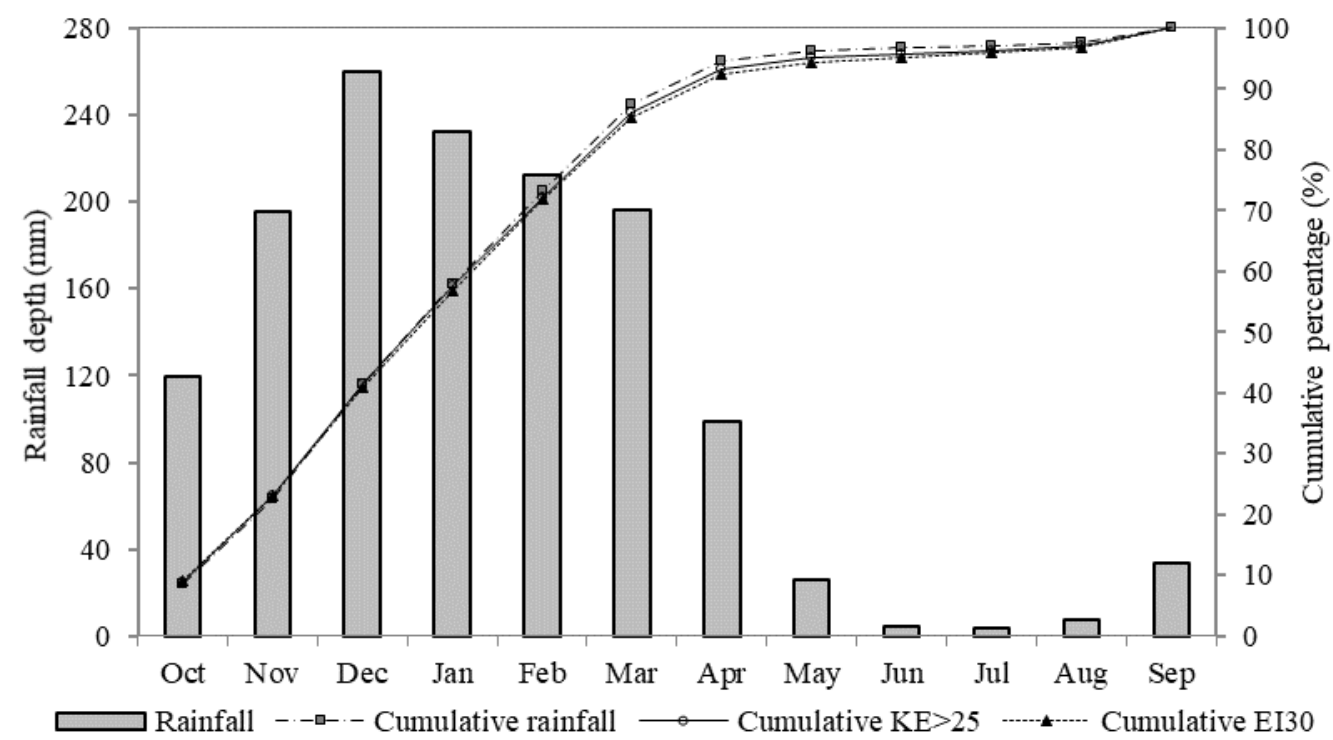

Figure 1. Monthly average values of rainfall $(\mathrm{mm})$ and cumulative percentage of rainfall and erosivity indices $\mathrm{EI}_{30}$ and KE>25 of the station of Formosa (GO), in the 1975 - 2008 period

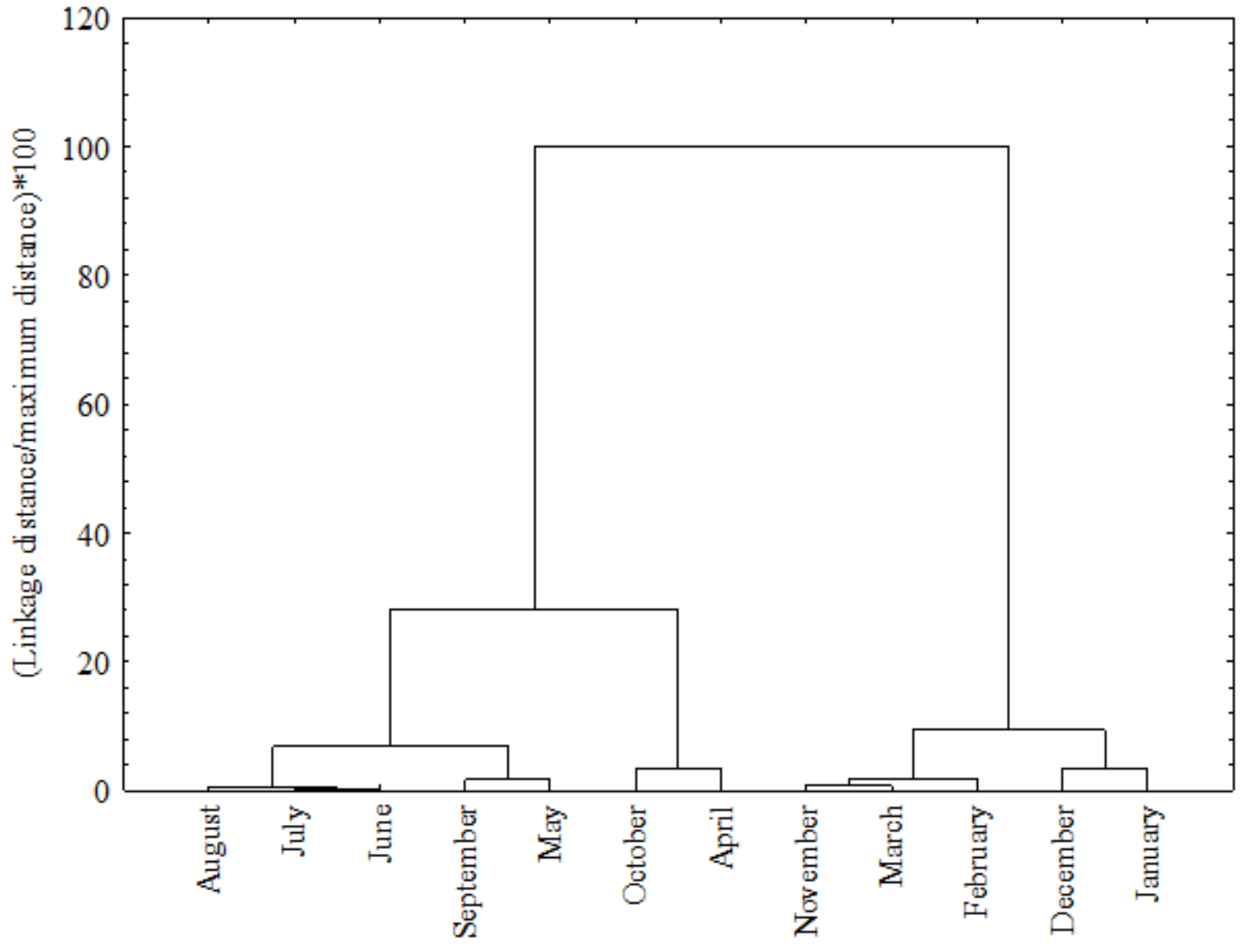

Figure 2. Ward's cluster analysis for months of the year in relation to the erosivity indices of the rainfalls of Formosa (GO) for the period from 1975 to 2008 
In the first major group (months April to September), it is possible to note a subgroup with the months from May to September (drought period) and a second subgroup with the months of April and October, which characterize the transition between rainy/drought and drought/rainy periods, respectively in the region (Figure 2). Within the second major group (November to March; right side of the Figure 2), the months of December and January stood out from the others with higher rainfall erosivity, as shown in Figure 1, Table 1 and Table 2.

The monthly average values of $\mathrm{EI}_{30}$ in the rainy period varied from 566.2 to $1,432.8 \mathrm{MJ} \mathrm{mm}$ $\mathrm{ha}^{-1} \mathrm{~h}^{-1}$ in April and December, respectively. The standard deviation and coefficient of variation for erosivity were very high, demonstrating the variability of this phenomenon in nature even in periods regular rainfalls. December was the month with lowest variability in erosivity (lower CV and SD) and, consequently, indicates higher rainfall regularity (Table 1). The rains in Brazil have high temporal and space variability. This may be related to the different types of rainfall, mainly those of the convective type (Fich et al., 2007), which predominate in the central Brazilian savanna (Silva et al., 1997b).

According to Wischmeier \& Smith (1978) the USLE is recommended for predicting average soil losses over long periods because this model utilizes as $\mathrm{R}$ factor; the average annual rainfall erosivity is not efficient in predicting short term losses due to their high variability.

September to early November is usually the period that precedes soil tillage which is then followed by planting of annual summer crops in Goiás and in most of Brazil. In recent decades, conventional tillage has been practically replaced by the no-tillage system in the Formosa region. When converting pastural areas to crop farms, conventional tillage is still used by producers to eliminate forage grass, destroy termite mounds and incorporate corrective materials such as limestone and gypsum. However, many areas just stopped doing conventional annual soil preparation, which lead to surfaces with low coverage of cultural residues that were prone to erosive processes. Due to this, the soil remains unprotected until the establishment of cover by aerial parts of crops. This increases the risk of erosion because $25.7 \%$ of the annual erosivity occurs in the period between September and November. This low soil coverage is attributed to the rapid decomposition of straw due to climatic conditions in the savanna (Silva et al., 2019). This requires the adoption of strategies such as the use and management of specific cover plants.

Likewise, in many rural properties harvesting is followed by second-crop planting in March, which has on average $13.9 \%$ of erosivity of the region. To favor the maintenance of soil cover with residues from the previous crop and to reduce the disturbance operations, farmers could adjust the tillage system or adopted a no-tillage system. From late autumn to early spring (between May and September), there are low risks of soil losses from erosion because rainfall erosivity corresponds to only $8.4 \%$ of the total annual $\mathrm{EI}_{30}$. 
Table 1. Month and annual values of erosivity $\mathrm{EI}_{30}$ obtained from pluviometric and pluviographic series for the Formosa (GO) station

\begin{tabular}{|c|c|c|c|c|c|c|c|c|c|c|c|c|c|}
\hline \multirow{2}{*}{ YEAR } & \multicolumn{13}{|c|}{ MONTH } \\
\hline & JAN & FEB & MAR & APR & MAY & JUN & JUL & AUG & SEP & OCT & NOV & DEC & Sum \\
\hline 1975 & $1,010.6$ & 856.2 & 648.3 & 712.7 & 103.7 & 0.0 & 46.1 & 0.0 & 125.1 & 582.1 & 512.4 & 511.4 & $5,108.6$ \\
\hline 1976 & 557.0 & $1,421.5$ & 648.8 & 162.1 & 739.9 & 0.0 & 33.1 & 0.0 & 549.5 & 585.6 & $1,579.3$ & $1,038.3$ & $7,315.2$ \\
\hline 1977 & $1,753.6$ & 759.0 & 595.5 & 943.7 & 270.4 & 186.9 & 0.0 & 0.0 & 236.7 & 363.4 & 360.9 & $1,923.2$ & $7,393.3$ \\
\hline 1978 & $1,330.7$ & 915.7 & $1,076.0$ & 712.1 & 316.0 & 0.0 & 239.2 & 0.0 & 119.7 & $1,260.7$ & $1,385.7$ & 916.6 & $8,272.3$ \\
\hline 1980 & $2,182.1$ & $2,925.5$ & 925.0 & 807.8 & 188.1 & 175.3 & 0.0 & 0.0 & 205.8 & 152.7 & $1,516.5$ & $1,770.9$ & $10,849.7$ \\
\hline 1981 & 872.6 & 427.8 & $1,167.4$ & 462.5 & 304.9 & 402.2 & 40.3 & 50.0 & 0.0 & $1,908.9$ & $1,840.3$ & 790.4 & $8,267.4$ \\
\hline 1982 & $2,956.9$ & 623.2 & $1,898.2$ & 495.7 & 780.0 & 0.0 & 20.2 & 0.0 & 115.7 & 637.3 & 352.5 & $1,067.2$ & $8,946.8$ \\
\hline 1983 & $2,625.7$ & $1,496.2$ & $1,250.5$ & 799.0 & 85.7 & 0.0 & 216.1 & 0.0 & 148.0 & 916.3 & $1,327.9$ & $1,499.1$ & $10,364.4$ \\
\hline 1984 & 779.9 & $1,088.0$ & 870.0 & $1,274.9$ & 80.2 & 0.0 & 0.0 & 243.8 & 261.0 & 614.3 & 716.1 & 777.1 & $6,705.2$ \\
\hline 1985 & $2,384.9$ & 882.5 & $1,432.4$ & 396.6 & 62.2 & 0.0 & 0.0 & 27.1 & 238.1 & 964.5 & $1,076.5$ & $3,114.9$ & $10,579.7$ \\
\hline 1986 & $1,520.6$ & $1,006.1$ & 786.9 & 222.8 & 19.4 & 0.0 & 213.2 & 944.9 & 51.1 & 1,1 & 415.3 & $1,683.6$ & $7,969.1$ \\
\hline 1987 & 614.0 & $1,056.0$ & $1,129.8$ & 757.0 & 148.0 & 0.0 & 0.0 & 0.0 & 745.9 & 391.0 & 1,28 & .9 & 63.5 \\
\hline 1988 & 446.9 & $1,408.6$ & $1,819.6$ & $1,086.0$ & 70.5 & 0.0 & 0.0 & 0.0 & 0.0 & 1,5 & 1,5 & $1,284.0$ & $9,236.6$ \\
\hline 1989 & 944.1 & 776.4 & 91 & 61.8 & 0.0 & 296.5 & 0.0 & 141.7 & 219.3 & 779.6 & $1,602.3$ & $3,766.9$ & $9,500.2$ \\
\hline 1990 & 405.0 & $1,033.0$ & 405.8 & 211.1 & 379.6 & 0.0 & 824.1 & 141.7 & 6.8 & 566.6 & 572.5 & 583.1 & $5,969.3$ \\
\hline 1991 & $1,271.5$ & 1,543 & $2,062.1$ & 331.3 & 9 & 0.0 & 0. & 0.0 & 317.5 & 647.6 & 1,5 & $1,898.7$ & $9,626.8$ \\
\hline 1992 & $1,687.1$ & $2,411.9$ & 593.8 & 718.5 & 41.5 & 0.0 & 0.0 & 118.8 & 174.9 & 969.7 & $1,378.4$ & $1,351.2$ & $9,445.8$ \\
\hline 1993 & 585.5 & $2,036.8$ & 222.3 & 435.7 & 94.0 & 0.0 & 0.0 & 60.4 & 515.2 & 469.6 & 680.2 & $1,845.9$ & $6,945.6$ \\
\hline 1994 & 943.0 & 722.0 & $2,824.9$ & 843.3 & 89.9 & 260.4 & 0.0 & 0.0 & 0.0 & 190.6 & $2,027.2$ & $1,336.2$ & $9,237.5$ \\
\hline 1995 & $1,324.0$ & 771.4 & $1,283.1$ & 586.7 & 271.7 & 0.0 & 0.0 & 0.0 & 0.0 & 699.8 & $1,572.0$ & $1,235.1$ & $7,743.9$ \\
\hline 1996 & 794.4 & 170.7 & $1,563.7$ & 478.2 & 74.7 & 0.0 & 0.0 & 396.9 & 196.4 & 647.6 & $1,073.1$ & $1,931.0$ & $7,326.7$ \\
\hline 1997 & $1,464.8$ & 377.3 & $1,295.4$ & 878.3 & 323.6 & 348.0 & 0.0 & 0.0 & 111.0 & 617.2 & 813.8 & $1,131.7$ & $7,361.1$ \\
\hline 1998 & $1,361.4$ & $1,478.8$ & 944.6 & 274.7 & 207.4 & 92.8 & 5.8 & 0.0 & 0.0 & 385.2 & $1,165.1$ & $1,260.1$ & $7,176.0$ \\
\hline 2002 & 197.3 & $1,414.4$ & 484.0 & 8.3 & 16 & 4.3 & 0 & 0.9 & 22.2 & 16.4 & 206.1 & 671.2 & $3,041.1$ \\
\hline 2003 & $1,968.5$ & 190.2 & 931.3 & 166.1 & 432.2 & 0 & 0 & 6.1 & 19.7 & 1.2 & 582.6 & 1397 & $5,694.9$ \\
\hline 2004 & $2,512.5$ & $3,256.8$ & $1,632.8$ & 793.8 & 0.4 & 0 & 0 & 1.2 & 0 & 76.9 & 72.8 & $2,025.2$ & $10,372.4$ \\
\hline 2005 & 987.5 & 661.2 & $1,998.8$ & 244.1 & 80.7 & 0 & 0 & 0 & $1,146.0$ & 20.3 & $1,227.3$ & $1,802.6$ & $8,168.5$ \\
\hline 2006 & 299.5 & $1,367.8$ & 528.3 & 700.8 & 2.8 & 0 & 0 & 2.1 & $1,286.6$ & $4,580.9$ & $1,264.4$ & 994.7 & $11,028.7$ \\
\hline 2007 & $1,142.4$ & $2,623.8$ & 188.0 & 209.5 & 0 & 0 & 0 & 0 & 0 & 161.8 & $3,667.1$ & 348.8 & $8,341.4$ \\
\hline 2008 & 958.5 & 577.5 & 516.7 & $1,209.3$ & 0 & 0 & 0 & 0 & 85.4 & 94.7 & 667.1 & 988.4 & $5,097.6$ \\
\hline MEAN & $1,262.7$ & $1,209.3$ & $1,087.9$ & 566.2 & 173.1 & 58.9 & 54.6 & 71.2 & 257.9 & 731.0 & $1,136.0$ & $1,432.8$ & $8,041.6$ \\
\hline S.D. & 715.0 & 761.6 & 602.4 & 334.7 & 199.8 & 116.7 & 157.5 & 184.3 & 333.8 & 842.5 & 695.0 & 718.9 & $1,847.7$ \\
\hline C.V. & 56.6 & 63.0 & 55.4 & 59.1 & 115.4 & 198.3 & 288.5 & 258.9 & 129.4 & 115.3 & 61.2 & 50.2 & 23.0 \\
\hline
\end{tabular}

SD: standard deviation. CV. Coefficient of variation

Table 2. Month and annual values of erosivity KE>25 index obtained from pluviometric and pluviographic series for the Formosa (GO) station

\begin{tabular}{|c|c|c|c|c|c|c|c|c|c|c|c|c|c|}
\hline \multirow{2}{*}{ YEAR } & \multicolumn{13}{|c|}{ MONTH } \\
\hline & JAN & FEB & MAR & APR & MAY & JUN & JUL & AUG & SEP & OCT & $\mathrm{NOV}$ & DEC & Sum \\
\hline 1975 & 16.0 & 13.5 & 10.2 & 11.1 & 1.5 & 0.0 & 0.6 & 0.0 & 1.9 & 9.1 & 8.1 & 8.1 & 80.1 \\
\hline 1976 & 8.8 & 22.5 & 10.3 & 2.5 & 10.9 & 0.0 & 0.4 & 0.0 & 8.2 & 9.2 & 25.0 & 16.5 & 114.1 \\
\hline 1977 & 27.8 & 12.0 & 9.4 & 14.7 & 4.0 & 2.3 & 0.0 & 0.0 & 3.5 & 5.7 & 5.7 & 30.5 & 115.6 \\
\hline 1978 & 21.1 & 14.5 & 17.0 & 11.1 & 4.6 & 0.0 & 2.9 & 0.0 & 1.8 & 19.8 & 21.9 & 14.5 & 129.2 \\
\hline 1980 & 34.5 & 46.2 & 14.6 & 12.6 & 2.8 & 2.2 & 0.0 & 0.0 & 3.1 & 2.4 & 24.0 & 28.1 & 170.4 \\
\hline 1981 & 13.8 & 6.8 & 18.4 & 7.2 & 4.5 & 5.0 & 0.5 & 0.7 & 0.0 & 29.9 & 29.1 & 12.5 & 128.4 \\
\hline 1982 & 46.8 & 9.8 & 30.0 & 7.7 & 11.5 & 0.0 & 0.2 & 0.0 & 1.7 & 10.0 & 5.6 & 16.9 & 140.3 \\
\hline 1983 & 41.6 & 23.6 & 19.8 & 12.5 & 1.3 & 0.0 & 2.7 & 0.0 & 2.2 & 14.4 & 21.0 & 23.8 & 162.6 \\
\hline 1984 & 12.3 & 17.2 & 13.7 & 19.9 & 1.2 & 0.0 & 0.0 & 3.2 & 3.9 & 9.6 & 11.3 & 12.3 & 104.7 \\
\hline 1985 & 37.7 & 13.9 & 22.6 & 6.2 & 0.9 & 0.0 & 0.0 & 0.4 & 3.5 & 15.1 & 17.0 & 49.4 & 166.8 \\
\hline 1986 & 24.1 & 15.9 & 12.4 & 3.5 & 0.3 & 0.0 & 2.6 & 12.4 & 0.8 & 17.3 & 6.6 & 26.7 & 122.5 \\
\hline 1987 & 9.7 & 16.7 & 17.9 & 11.8 & 2.2 & 0.0 & 0.0 & 0.0 & 11.1 & 6.1 & 20.3 & 32.3 & 128.0 \\
\hline 1988 & 7.1 & 22.3 & 28.8 & 16.9 & 1.0 & 0.0 & 0.0 & 0.0 & 0.0 & 23.9 & 25.3 & 20.4 & 145.5 \\
\hline 1989 & 14.9 & 12.3 & 14.4 & 1.0 & 0.0 & 3.7 & 0.0 & 1.9 & 3.3 & 12.2 & 25.3 & 59.7 & 148.7 \\
\hline 1990 & 6.4 & 16.3 & 6.4 & 3.3 & 5.6 & 0.0 & 10.1 & 1.9 & 12.6 & 8.9 & 9.0 & 9.2 & 89.7 \\
\hline 1991 & 20.1 & 24.4 & 32.6 & 5.2 & 0.1 & 0.0 & 0.0 & 0.0 & 4.7 & 10.1 & 24.4 & 30.1 & 151.8 \\
\hline 1992 & 26.7 & 38.1 & 9.4 & 11.2 & 0.6 & 0.0 & 0.0 & 1.6 & 2.6 & 15.2 & 21.8 & 21.4 & 148.6 \\
\hline 1993 & 9.3 & 32.2 & 3.5 & 6.8 & 1.4 & 0.0 & 0.0 & 0.8 & 7.6 & 7.4 & 10.7 & 29.3 & 108.9 \\
\hline 1994 & 14.9 & 11.4 & 44.6 & 13.1 & 1.3 & 3.3 & 0.0 & 0.0 & 0.0 & 3.0 & 32.0 & 21.2 & 144.9 \\
\hline 1995 & 21.0 & 12.2 & 20.3 & 9.1 & 4.0 & 0.0 & 0.0 & 0.0 & 0.0 & 11.0 & 24.8 & 19.6 & 121.9 \\
\hline
\end{tabular}




\section{Macrothink}

\begin{tabular}{|c|c|c|c|c|c|c|c|c|c|c|c|c|c|}
\hline 1996 & 12.6 & 2.7 & 24.7 & 7.5 & 1.1 & 0.0 & 0.0 & 5.2 & 2.9 & 10.1 & 17.0 & 30.6 & 114.4 \\
\hline 1997 & 23.2 & 6.0 & 20.5 & 13.7 & 4.8 & 4.4 & 0.0 & 0.0 & 1.6 & 9.7 & 12.9 & 17.9 & 114.5 \\
\hline 1998 & 21.5 & 23.4 & 14.9 & 4.3 & 3.1 & 1.2 & 0.1 & 0.0 & 0.0 & 6.0 & 18.4 & 20.0 & 112.8 \\
\hline 2002 & 2.1 & 3.3 & 9.3 & 0 & 0 & 0 & 0 & 0 & 0.7 & 1.2 & 4.6 & 14.8 & 36.0 \\
\hline 2003 & 38.8 & 5.6 & 19.8 & 4.2 & 7.3 & 0 & 0 & 0.4 & 0 & 0 & 16.3 & 29.6 & 119 \\
\hline 2004 & 45.5 & 46.1 & 28.9 & 12.3 & 0 & 0 & 0 & 0 & 0 & 3.2 & 1.1 & 30.5 & 167.6 \\
\hline 2005 & 17.8 & 12.3 & 33 & 5.5 & 2.6 & 0 & 0 & 0 & 16.1 & 0 & 19.9 & 28.4 & 135.6 \\
\hline 2006 & 6.4 & 16.5 & 8.9 & 9 & 0 & 0 & 0 & 0 & 13.6 & 55.6 & 20.9 & 14.4 & 145.3 \\
\hline 2007 & 18.4 & 36.7 & 5.1 & 3.3 & 0 & 0 & 0 & 0 & 0 & 2.8 & 43.6 & 10.6 & 120.5 \\
\hline 2008 & 16.8 & 9.3 & 9.5 & 16.2 & 0 & 0 & 0 & 0 & 1.1 & 1.4 & 15.9 & 12.9 & 83.1 \\
\hline MEAN & 20.6 & 18.1 & 17.7 & 8.8 & 2.6 & 0.7 & 0.7 & 0.9 & 3.6 & 11.0 & 18.0 & 23.1 & 125.7 \\
\hline S.D. & 11.9 & 11.5 & 9.5 & 5.0 & 3.0 & 1.5 & 1.9 & 2.4 & 4.4 & 10.8 & 9.2 & 11.2 & 28.7 \\
\hline C.V. & 58.0 & 63.2 & 53.6 & 56.4 & 114.0 & 198.9 & 288.5 & 256.2 & 121.2 & 97.8 & 51.0 & 48.4 & 22.8 \\
\hline
\end{tabular}

SD: standard deviation. CV. Coefficient of variation

On average, annual erosivity varied from 3,041.1 to $11,028.7 \mathrm{MJ} \mathrm{mm} \mathrm{ha}^{-1} \mathrm{~h}^{-1} \mathrm{year}^{-1}$, for the index $\mathrm{EI}_{30}$, and from 36 to $170.4 \mathrm{MJ}$ ha year ${ }^{-1}$ through the index $\mathrm{KE}>25$, in 2002 and 2006/1980, respectively. The average annual erosivity for Formosa (GO) in the period studied was 8,041.6 MJ mm ha ${ }^{-1} \mathrm{~h}^{-1}$ year $^{-1}$ and to $125.7 \mathrm{MJ} \mathrm{ha}^{-1}$ year $^{-1}$, for $\mathrm{EI}_{30}$ and $\mathrm{KE}>25$, respectively (Table 1 and Table 2). The $\mathrm{EI}_{30}$ value was close to those found in localities of Brasília (DF-Brazil) (8,319) (Dedecek, 1988), Goiânia (GO-Brazil) $(8,353)$ (Silva et al., 1997b), Flechas (MT-Brazil) (7,830) (Morais et al., 1991) and Cuiabá (MT-Brazil) $(8,810$ MJ $\mathrm{mm} \mathrm{ha}^{-1} \mathrm{~h}^{-1}$ year $\left.{ }^{-1}\right)($ Almeida et al. 2011), which are all under Aw climate.

Based on the classification proposed by Carvalho (1994), the erosivity of Formosa (GO) fits in the category Strong $\left(7,357<\mathrm{R}<9,810 \mathrm{MJ} \mathrm{mm} \mathrm{ha}^{-1} \mathrm{~h}^{-1}\right.$ year $\left.^{-1}\right)$. This suggests that special attention should be paid to agricultural practices that promote soil mobilization especially when terrain surface remains uncovered during the previously mentioned critical periods.

Working with clayey Dark Red Latosol in the municipality of Goiânia (GO), Silva et al. (1997a) found a soil loss of $29.3 \mathrm{t} \mathrm{ha}^{-1} \mathrm{year}^{-1}$ for an average annual erosivity of 7,364.5 MJ $\mathrm{mm} \mathrm{ha} \mathrm{h}^{-1} \mathrm{~h}^{-1}$ year ${ }^{-1}$. These authors found soil loss of $112.58 \mathrm{t} \mathrm{ha}^{-1} \mathrm{year}^{-1}$ associated with the extreme $\mathrm{EI}_{30}$ index of $12,315 \mathrm{MJ} \mathrm{mm} \mathrm{ha}^{-1} \mathrm{~h}^{-1}$ year $^{-1}$, which is close to the maximum annual $\mathrm{EI}_{30}$ found for Formosa (GO) of 11,028.7 MJ mm ha-1 $\mathrm{h}^{-1} \mathrm{year}^{-1}$ in 2006.

Based on the pluviographic series (2002 to 2008), there were 990 individual rainfalls, of which 295 were classified as erosive $(29.8 \%$ ), and responsible for $80 \%$ of the rainfall depth. Erosive rainfalls corresponded to $52.9 \%, 24.7 \%$ and $22.4 \%$ for the patterns Advanced, Intermediate and Delayed, respectively (Table 3). For rainfall depth and erosivity indices, similar results were obtained (Table 3). These results were consistent with the work of Evangelista et al. (2016) for Goiânia (GO) in relation to the patterns Advanced and Intermediate, but varied when compared to the pattern Delayed, which may be related to the effect of the urban area (higher surface temperature), as well as to the difference in the size of the data series. 
Table 3. Number of erosive rainfalls, average annual rainfall depth and average annual cumulative erosivity indices in the rainfall patterns Advanced (AD), Intermediate (IN) and Delayed (DE) in Formosa (GO), in the period from 2002 to 2008

\begin{tabular}{|c|c|c|c|c|c|c|c|c|}
\hline \multirow{4}{*}{$\begin{array}{c}\text { Rainfall } \\
\text { pattern }\end{array}$} & \multicolumn{2}{|c|}{ Number of rains } & \multicolumn{2}{|c|}{ Rainfall depth } & \multicolumn{4}{|c|}{ Erosivity indices } \\
\hline & \multirow{3}{*}{ Absolute } & \multirow{3}{*}{$\%$} & \multirow{3}{*}{$\mathrm{mm}$} & \multirow{3}{*}{$\%$} & $\mathrm{EI}_{30}$ & \multirow{2}{*}{\multicolumn{2}{|c|}{$\mathrm{KE}>25$}} & \multirow{3}{*}{$\%$} \\
\hline & & & & & & & & \\
\hline & & & & & MJ mm ha ${ }^{-1} h^{-1}$ year $^{-1}$ & & MJ ha-1 year $^{-1}$ & \\
\hline $\mathrm{AD}$ & 156 & 52.9 & 548.1 & 54.1 & $4,102.2$ & 58.2 & 64.4 & 57.0 \\
\hline IN & 73 & 24.7 & 282.6 & 27.9 & $2,041.3$ & 29.0 & 31.6 & 28.0 \\
\hline $\mathrm{DE}$ & 66 & 22.4 & 183.1 & 18.1 & 902.4 & 12.8 & 17.0 & 15.0 \\
\hline TOTAL & 295 & 100 & $1,013.79$ & 100 & $7,045.86$ & 100 & 113.0 & 100 \\
\hline
\end{tabular}

Carvalho et al. (2010) studied erosion under natural rainfall in Argissolo Vermelho Amarelo (Ultisol) in Seropédica (RJ-Brazil) and found superiority of erosivity in the Advanced pattern in the frequency of erosive rainfalls and cumulative erosivity. These authors found soil losses of $35.1 \%, 6.6 \%$ and $58.3 \%$ for the patterns Advanced, Intermediate and Delayed, respectively. Bazzano et al. (2010) pointed out that those rainfalls with intensity peaks at the end of its duration led to larger soil losses due to the effect of accumulated moisture on disaggregation, surface sealing and capacity of transport of soil particles. Aquino et al. (2013) studied soil loss in typically dystrophic Red Latosol in Lavras (MG-Brazil) and also observed a predominance of rainfalls with Advanced pattern, but the total soil losses were larger in the patterns Advanced (54\%), followed by Intermediate (28\%) and Delayed (18\%). In this study, the amount of rainfalls seems to have prevailed on the total soil loss when compared to the effect of previous moisture.

According to Table 4, there was no significant difference in the rainfall erosivity measured by the indices $\mathrm{EI}_{30}$ and $\mathrm{KE}>25$ between the months of the rainy period in each rainfall pattern. The high coefficient of variation observed in these attributes may have contributed to this result. In a statistical analysis of the rainfall patterns for the index EI 30 , the rainfalls in the patterns Advanced and Intermediate were more erosive than those in the Delayed pattern in February. This behavior was also observed between the means of the patterns (mean of all months in each pattern). In the February month, since usually summer crops cover all soil surfaces, the risks of erosion are lower than in the periods of soil tillage, crop establishment and harvest. 
Table 4. Distributions of $\mathrm{EI}_{30}$ and $\mathrm{KE}>25$, obtained based on erosive rainfalls for individual events along the rainy period for the rainfall patterns in Formosa $(\mathrm{GO})$

\begin{tabular}{|c|c|c|c|c|}
\hline \multirow{2}{*}{ Month } & \multicolumn{3}{|c|}{ Rainfall Pattern } & \multirow{2}{*}{$\begin{array}{l}\text { Mean of the } \\
\text { Month }\end{array}$} \\
\hline & Advanced & Intermediate & Delayed & \\
\hline & \multicolumn{4}{|c|}{$\mathrm{EI}_{30}\left(\mathrm{MJ} \mathrm{mm} \mathrm{ha}^{-1} \mathrm{~h}^{-1}\right)^{*}$} \\
\hline January & $148.64 \mathrm{aA}$ & $208.80 \mathrm{aA}$ & $75.80 \mathrm{aA}$ & $146.24 \mathrm{a}$ \\
\hline February & $212.48 \mathrm{aA}$ & $205.33 \mathrm{aA}$ & $73.75 \mathrm{aB}$ & $178.64 \mathrm{a}$ \\
\hline March & $138.00 \mathrm{aA}$ & $198.22 \mathrm{aA}$ & $53.27 \mathrm{aA}$ & $125.52 \mathrm{a}$ \\
\hline April & $176.00 \mathrm{aA}$ & $167.00 \mathrm{aA}$ & $26.00 \mathrm{aA}$ & $148.05 \mathrm{a}$ \\
\hline October & $350.30 \mathrm{aA}$ & $345.00 \mathrm{aA}$ & $71.00 \mathrm{aA}$ & $283.64 \mathrm{a}$ \\
\hline November & $268.27 \mathrm{aA}$ & $145.28 \mathrm{aA}$ & $56.87 \mathrm{aA}$ & $199.30 \mathrm{a}$ \\
\hline December & $126.96 \mathrm{aA}$ & $209.14 \mathrm{aA}$ & $129.00 \mathrm{aA}$ & $149.67 \mathrm{a}$ \\
\hline $\begin{array}{c}\text { Mean of the } \\
\text { Pattern }\end{array}$ & $187.06 \mathrm{~A}$ & $200.73 \mathrm{~A}$ & $79.06 \mathrm{~B}$ & \\
\hline $\mathrm{CV}(\%)$ & \multicolumn{4}{|c|}{155.64} \\
\hline & \multicolumn{4}{|c|}{$\mathrm{KE}>25\left(\mathrm{MJ} \mathrm{ha}^{-1}\right)^{* *}$} \\
\hline January & $2.64 \mathrm{aA}$ & $3.70 \mathrm{aA}$ & $1.40 \mathrm{aA}$ & $2.60 \mathrm{a}$ \\
\hline February & $3.39 \mathrm{aA}$ & $2.78 \mathrm{aA}$ & $1.50 \mathrm{aA}$ & $2.75 \mathrm{a}$ \\
\hline March & $2.46 \mathrm{aA}$ & $3.22 \mathrm{aA}$ & $1.54 \mathrm{aA}$ & $2.39 \mathrm{a}$ \\
\hline April & $2.28 \mathrm{aA}$ & $2.78 \mathrm{aA}$ & $0.67 \mathrm{aA}$ & $2.26 \mathrm{a}$ \\
\hline October & $4.50 \mathrm{aB}$ & $5.00 \mathrm{aA}$ & $0.50 \mathrm{aB}$ & $3.65 \mathrm{a}$ \\
\hline November & $4.00 \mathrm{aA}$ & $2.43 \mathrm{aA}$ & $150 \mathrm{aA}$ & $3.16 \mathrm{a}$ \\
\hline December & $2.26 \mathrm{aA}$ & $3.50 \mathrm{aA}$ & $2.33 \mathrm{aA}$ & $2.62 \mathrm{a}$ \\
\hline $\begin{array}{l}\text { Mean of the } \\
\text { Pattern }\end{array}$ & $2.99 \mathrm{~A}$ & $3.17 \mathrm{~A}$ & $1.59 \mathrm{~B}$ & \\
\hline CV (\%) & \multicolumn{4}{|c|}{117.67} \\
\hline
\end{tabular}

Means followed by the same letter, in the columns, for each pattern and mean of months (lowercase letters), and in the rows between rainfall patterns and means of the patterns (uppercase letters), do not differ by Scott-Knott test $(\mathrm{p}<0.05)$. * Values transformed in the analysis to $\log$ of the variable. **Values transformed in the analysis to $\log ($ variable +1$)$.

For $\mathrm{KE}>25$, based on the means of the patterns, similar to $\mathrm{EI}_{30}$, the highest erosivity indices occurred with the rainfall patterns Intermediate and Advanced (Table 4). In October, the rainfall erosivity in the Intermediate pattern is higher than in other patterns in the municipality of Formosa (GO). Although this month corresponds to $9 \%$ of the annual erosivity, the erosion promoted by this pattern is of concern because due to accumulated moisture of the soil and uncovered soil using conventional tillage practices, or no-tillage practices accompanied by sowing along the ramp, regardless of slope, without adopting terraces.

In relation to the return period of erosivity ( $\mathrm{R}$ factor), the average annual value of 8,041.6 $\mathrm{MJ}$ $\mathrm{mm} \mathrm{ha}^{-1} \mathrm{~h}^{-1}$ year $^{-1}$ was associated with $52.84 \%$ of probability $(\mathrm{P})$ of being equaled or surpassed, at least once on average, every 1.89 years in Formosa (GO) (Figure 3a). Based on Figure 3, it is possible to estimate rainfall erosivity for different return periods or probability of occurrence for this locality.

The values of $T$ found were relatively close to those obtained by Almeida et al. (2012) for three municipalities in Mato Grosso (MT-Brazil) $(\mathrm{P}=43 \%$ and $\mathrm{T}=2.33$ years) and Moreti et al. (2003) in São Manuel (SP-Brazil) $(\mathrm{P}=42.9 \%$ and $\mathrm{T}=2.3$ years).

For the average annual erosivity measured by the index KE $>25$ for Formosa, the results were $53.48 \%$ and 1.87 years for $\mathrm{P}$ and $\mathrm{T}$ (Figure $3 \mathrm{~b}$ ), respectively, as observed for the index $\mathrm{EI}_{30}$. For 30 localities in the Rio de Janeiro state, Machado et al. (2013) obtained results of KE>25 
associated with P from 48.8 to $54.4 \%$ and T from 1.8 to 2.1 years, close to those found for Formosa, except for the climatic differences.
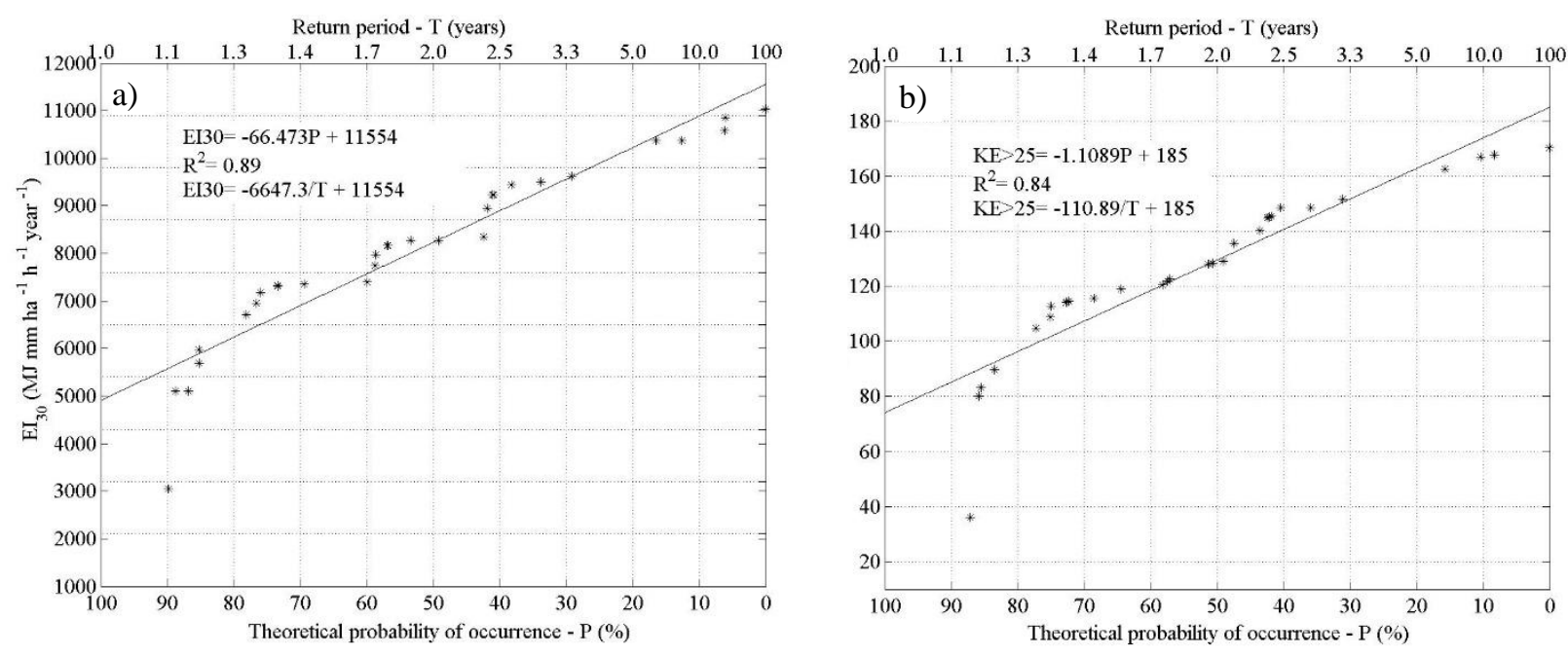

Figure 3. Return period and theoretical probability of occurrence of the erosivity indices EI30 (a) and $\mathrm{KE}>25$ (b) for Formosa (GO)

The values of erosivity found for the station of Formosa were 8,230, 10,225, 10,889, 11,222, 11,421 and 11,488 $\mathrm{MJ} \mathrm{mm} \mathrm{ha}^{-1} \mathrm{~h}^{-1}$ year $^{-1}$ (Figure 3) for return periods commonly used in the literature of 2, 5, 10, 20, 50 and 100 years, respectively. For the same return periods, the obtained values of KE> 25 were $130,163,174,179,183$ and $184 \mathrm{MJ}^{-1}$ year $^{-1}$. The erosivity expected for the return period of 2 years, measured by both $\mathrm{EI}_{30}$ and $\mathrm{KE}>25$, respectively, was close to the average annual erosivity of $\mathrm{R}$ factor $\left(\mathrm{EI}_{30}\right)$. This occurs because the probability of occurrence of these indices is almost 2 years (1.89 years). For the maximum erosivity observed in the pluviometric series, which was $11,028.7 \mathrm{MJ} \mathrm{mm} \mathrm{ha} \mathrm{m}^{-1} \mathrm{~h}^{-1}$ year $^{-1}$ in 2006 (Table 1), this magnitude was related to return period (T) of 12.6 years.

Taking the $\mathrm{EI}_{30}$ index as an example, which does not vary much differently from $\mathrm{KE}>25$, the variation in annual erosivity was $24.2 \%, 6.5 \%, 3.1 \%, 1.8 \%$ and $0.6 \%$ with the increase in the above-mentioned return periods from 2 to 100 years. This demonstrates that the largest variation in erosivity occurred from 2 to 5 years; for rainfall events related to return periods with more than 5 years of recurrence, there is little variation in the average annual erosivity corroborating the study of Carvalho et al. (2010) for Seropédica (RJ-Brazil). Thus, the use of the $\mathrm{R}$ factor of Formosa in the USLE as is normally done (without considering the return period) does not considerably underestimate erosivity for this locality.

\section{Conclusion}

In conclusion, this study demonstrated that rainfall erosive potential is concentrated in the periods between November and March (corresponding to $76.2 \%$ of $\mathrm{EI}_{30}$ and $77.5 \%$ of $\mathrm{KE}>25$ of the annual erosive potential) with the months of December and January having the highest erosivity. The predominant hydrological pattern in the region is the Advanced. Rainfalls (individual events) of Advanced and Intermediate patterns have higher erosivity in the 
months of February $\left(\mathrm{EI}_{30}\right)$, October (KE>25 - intermediate pattern) and for the mean of the patterns. The average annual erosivity of the rainfalls is $8,041.6 \mathrm{MJ} \mathrm{mm} \mathrm{ha-1} \mathrm{h}^{-1}$ year-1 for $\mathrm{EI}_{30}$ (R factor of USLE) and 125.7 $\mathrm{MJ} \mathrm{ha}^{-1}$ year $^{-1}$ for $\mathrm{KE}>25$, and is expected to occur at least once every 1.89 and 1.87 years, on average, with theoretical probabilities of occurrence of $52.84 \%$ and $53.48 \%$, respectively. Increment in return periods does not increase the expected erosivity at the same magnitude for the locality under study.

\section{Acknowledgements}

We thank the National Institute of Meteorology (INMET) and National Agency of Waters /HIDROWEB for availing data and the Federal Institute Goiano for financial support to conduct the study. We acknowledge the National Council for Scientific and Technological Development $(\mathrm{CNPq}-$ Brazil) for their support in English translation and revising the manuscript (Process 310604/2018-4).

\section{References}

Almagro, A., Oliveira, P. T. S., Nearing, M. A., \& Hagemann, S. (2017). Projected climate change impacts in rainfall erosivity over Brazil. Scientific Reports, 7(1), 8130. https://doi.org/10.1038/s41598-017-08298-y

Almeida, C. O. S., Amorim, R. S. S., Couto, E. G., Eltz, F. L. F., \& Borges, L. E. C. (2011). Erosive potential of rainfall in Cuiabá, MT: Distribution and correlation with rainfall. Revista Brasileira de Engenharia Agricola e Ambiental, 15(2), 178-184. https://doi.org/10.1590/S1415-43662011000200011

Almeida, C. O. S., Amorim, R. S. S., Eltz, F. L. F., Couto, E. G., \& Jordani, S. A. (2012). Erosividade da chuva em municípios do Mato Grosso: Distribuição sazonal e correlações com dados pluviométricos. Revista Brasileira de Engenharia Agricola e Ambiental, 16(2), 142-152. https://doi.org/10.1590/S1415-43662012000200003

Alvares, C. A., Stape, J. L., Sentelhas, P. C., De Moraes Gonçalves, J. L., \& Sparovek, G. (2013). Köppen's climate classification map for Brazil. Meteorologische Zeitschrift, 22(6), 711-728. https://doi.org/10.1127/0941-2948/2013/0507

Aquino, R. F., Silva, M. L. N., de Freitas, D. A. F., Curi, N., \& Avanzi, J. C. (2013). Soil losses from typic cambisols and red latosol as related to three erosive rainfall patterns. Revista Brasileira de Ciência do Solo, 37(1), 213-220. https://doi.org/10.1590/S0100-06832013000100022

Arai, F. K.; Conçalves, G. G. G., Pereira, S. B.; Comunello, E., Vitorino, A. C. T.; Daniel, O. (2010). Rainfall and erosion spacializationin Dourados River Basin, MS, Brazil. Engenharia Agrícola, 30(5), 922-931. https://doi.org/10.1590/S0100-69162010000500014

Back, Á. J., Wildner, L. do P., \& Garcez, J. G. (2019). Análise de chuvas intensas visando ao dimensionamento de estruturas de conservação do solo para a região de Chapecó, Santa Catarina. Agropecuária $\quad$ Catarinense, $\quad 32(3), \quad$ 95-100. https://doi.org/10.22491/rac.2019.v32n3.14 
Bazzano, M. G. P., Eltz, F. L. F., \& Cassol, E. A. (2010). Erosividade e características hidrológicas das chuvas de Rio Grande (RS). Revista Brasileira de Ciência do Solo, 34, 235-244. https://doi.org/10.1590/S0100-06832010000100024

Bertol, I., Schick, J., Batistela, O., Leite, D., Visentin, D., \& Cogo, N. P. (2002). Erosividade das chuvas e sua distribuição entre 1989 e 1998 no município de Lages (SC). Revista $\begin{array}{lllll}\text { Brasileira de Ciência do } & \text { Solo, } & \text { 26(2), }\end{array}$ https://doi.org/10.1590/s0100-06832002000200019

Bertol, Ildegardis, Luciano, R. V., Bertol, C., \& Bagio, B. (2017). Nutrient and organic carbon losses, enrichment rate, and cost of water erosion. Revista Brasileira de Ciência do Solo, 41. https://doi.org/10.1590/18069657rbcs20160150

Carvalho, D. F. de, Machado, R. L., Evangelista, A. W. P., Khoury Júnior, J. K., \& Silva, L. D. B. da. (2010). Distribuição, probabilidade de ocorrência e período de retorno dos índices de erosividade $\mathrm{EI}_{30}$ e $\mathrm{KE}>25$ em Seropédica-RJ. Engenharia Agrícola, 30(2), 245-252. https://doi.org/10.1590/s0100-69162010000200006

Carvalho, N. de O. (1994). Hidrossedimentologia prática. Rio de Janeira: Companhia de Pesquisa de Recursos Minerais, 372p.

Cassol, E. A., Eltz, F. L. F., Martins, D., Lemos, A. M., Lima, V. S., Bueno, A.C. (2008). Erosividade, padrões hidrológicos, período de retorno e probabilidade de ocorrência das chuvas em São Borja, RS. Revista Brasileira de Ciência do Solo, 32(3), 1239-1251. https://doi.org/10.1590/S0100-06832008000300032.

Climate-Data.Org. (n.d.). Clima Formosa. Retrieved June 17, 2020, from https://pt.climate-data.org/america-do-sul/brasil/goias/formosa-43207/

Dedecek, R. A. (1988). Fatores de erosividade da chuva, enxurrada e perdas de solo sob condições de cerrado. Pesquisa Agropecuária Brasileira, 23(12), 1431-1438.

Edwards, W. M., \& Owens, L. B. (1991). Large storm effects on total soil erosion. Journal of Soil and Water Conservation, 46(1), 75-78.

Eltz, F. L. F., Mehl, H. U., \& Reichert, J. M. (2001). Perdas de solo e água em entressulcos em um Argissolo Vermelho-Amarelo submetido a quatro padrões de chuva. Revista Brasileira de Ciência do Solo, 25(2), 485-493. https://doi.org/10.1590/s0100-06832001000200024

Evangelista, A. W. P., Carvalho, L. G. de, Dantas, A. A. A., \& Bernardino, D. T. (2006). Potencial erosivo das chuvas em Lavras, MG: Distribuição, probabilidade de ocorrência e período de retorno. Irriga, 11(1), 1-11. https://doi.org/10.15809/irriga.2006v11n1p1-11

Evangelista, A. W. P., Correchel, V., Arantes, N. R. de M., Alves Junior, J., \& Casaroli, D. (2016). Padrões hidrológicos e período de retorno das chuvas erosivas de Goiânia - GO. Global Science and Technology, 9(2), 1-12.

Ferreira, D. F., Ferreira, F., \& Ferreira, D. (2007). SISVAR: sistema de análise de variância 
para dados balanceados. Versão 5.0. UFLA.

Fisch, G., Vendrame, I. F., \& Hanaoka, P.C. de M. (2007). Variabilidade espacial da chuva durante o experimento LBA/TRMM 1999 na Amazônia. Acta Amazonica, 37(4), 583-590. https://doi.org/10.1590/S0044-59672007000400013

Flanagan, D. C., Foster, G. R., \& Moldenhauer, W. C. (1988). Storm pattern effect on infiltration, runoff, and erosion. Transactions of the ASAE, 31(2), 414-420.

Horner, W. W., \& Jens, S. W. (1942). Surface runoff determination from rainfall without using coefficients. Transactions of the American Society of Civil Engineers, 107(1), 1039-1075.

Hudson, N. W. (1995). Soil Conservation (3 ed.). Londres: BT Batsford, 391p.

IBGE. (2017). Formosa: Produto Interno Bruto dos Municípios. Available in: https://cidades.ibge.gov.br/brasil/go/formosa/pesquisa/38/47001?tipo=ranking\&indicador=47 008. Access in: 07 oct. 2020.

Machado, R. L., Carvalho, D. F. de, Rouws, J. R. C., Gomes, D. P., \& Eduardo, E. N. (2013). Erosividade das chuvas associada a períodos de retorno e probabilidade de ocorrência no Estado do Rio de Janeiro. Revista Brasileira de Ciência do Solo, 37(2), 529-547. https://doi.org/10.1590/S0100-06832013000200024

Marques, J. J. G. S. M., Alvarenga, R. C., Curi, N., Santana, D. P., \& Silva, M. L. N. (1997). Índices de erosividade da chuva, perdas de solo e fator erodibilidade para dois solos da região dos cerrados - primeira aproximação. Revista Brasileira de Ciência do Solo, 21(3), 427-434. https://doi.org/10.1590/s0100-06831997000300011

Morais, L. F. B., Silva, V. da, Naschenveng, T. M. C., Hardoin, P. C., \& Almeida, J. E. L. (1991). Índice $\mathrm{EI}_{30}$ e sua relação com o coeficiente de chuva do sudoeste do Mato Grosso. Revista Brasileira de Ciência do Solo, 15(3), 339-344. https://doi.org/10.1590/S0100-06832003000400016

Moreti, D., Carvalho, M. P., Mannigel, A. R., \& Medeiros, L. R. (2003). Importantes características de chuva para a conservação do solo e da água no município de São Manuel (SP). Revista Brasileira de Ciência do Solo, 27(4), 713-725. https://doi.org/10.1590/s0100-06832003000400016

Ran, Q., Su, D., Li, P., \& He, Z. (2012). Experimental study of the impact of rainfall characteristics on runoff generation and soil erosion. Journal of Hydrology, 424, 99-111. https://doi.org/10.1016/j.jhydrol.2011.12.035

Roque, C. G., Carvalho, M. P., \& Prado, R. M. (2001). Fator erosividade da chuva de Piraju (SP): distribuição, probabilidade de ocorrência, período de retorno e correlação com o coeficiente de chuva. Revista Brasileira de Ciência do Solo, 25(1), 147-156. https://doi.org/10.1590/s0100-06832001000100016

Schick, J., Bertol, I., Cogo, N. P., Gonzáles, A. P. (2014). Erosividade das chuvas de Lages, 
Santa Catarina. Revista Brasileira de Ciência do Solo, 38(6), 1890-1905. https://doi.org/10.1590/S0100-06832014000600024.

Silva, A. G.; Assis, R. L.; Oliveira, C. A. A., Ferreira, C. J. B., Teixeira, I. R., Almeida, K. L., Carmo, E. L. (2019). Variabilidade dos atributos físicos do solo e dinâmica da palhada em sistema integração lavoura-pecuária no Cerrado. Revista Brasileira de Milho e Sorgo, 18(3), 429-440. https://doi.org/10.18512/1980-6477/rbms.v18n3p429-440

Silva, M. L. N., Freitas, P. L. de, Blancaneaux, P., Curi, N., \& Lima, J. M. (1997a). Relação entre parâmetros da chuva e perdas de solo e determinação da erodibilidade de um Latossolo Vermelho-Escuro em Goiânia (GO). Revista Brasileira de Ciência do Solo, 21, 131-137.

Silva, M. L. N., Freitas, P. L., Blancaneaux, P., \& Curi, N. (1997b). Índices de erosividade das chuvas da região de Goiânia, GO. Pesquisa Agropecuária Brasileira, 32(10), 977-985.

Tejon, L. L. (2018). O Brasil tem problema, mas a solução pode estar na região de Formosa. Available in: https://blogs.canalrural.com.br/agrosuperacao/2018/08/20/brasil-tem-solucao-formosa/.Acces s in: 07 oct. 2020.

Valvassori, M. L., Back, A. J. (2014). Avaliação do potencial erosivo das chuvas em Urussanga, SC, no período de 1980 a 2012. Revista Brasileira de Ciência do Solo, 38(3), 1011-1019. https://doi.org/10.1590/S0100-06832014000300033

Wang, W., Yin, S., Xie, Y., Liu, B., \& Liu, Y. (2016). Effects of four storm patterns on soil loss from five soils under natural rainfall. Catena, 141, 56-65. https://doi.org/10.1016/j.catena.2016.02.019

Wischmeier, W. H. (1959). A Rainfall Erosion Index for a Universal Soil-Loss Equation 1. Soil Science Society of America Journal, 23(3), 246-249.

Wischmeier, W. H., \& Smith, D. D. (1958). Rainfall energy and its relationship to soil loss. Eos, Transactions American Geophysical Union, 39(2), 285-291. https://doi.org/10.1029/TR039i002p00285

Wischmeier, W. H., \& Smith, D. D. (1978). Predicting rainfall erosion losses: a guide to conservation planning (Issue 537). Hyattsville: Department of Agriculture, Science and Education Administration, 67p.

\section{Copyright Disclaimer}

Copyright for this article is retained by the author(s), with first publication rights granted to the journal.

This is an open-access article distributed under the terms and conditions of the Creative Commons Attribution license (http://creativecommons.org/licenses/by/4.0/). 